\title{
Sprawozdanie z XXVIII Międzynarodowej Konferencji Naukowej „Współpraca samorządu terytorialnego oraz grup dyspozycyjnych w zapewnianiu bezpieczeństwa społeczności lokalnych" \\ DOI: $10.19195 / 2083-7763.7 .21$
}

W dniach 11-12 maja 2017 roku w Hali Orbita we Wrocławiu odbyła się kolejna edycja cyklicznie organizowanej Międzynarodowej Konferencji Naukowej, obejmującej zagadnienia bezpieczeństwa w podejściu socjologii grup dyspozycyjnych. Tym razem problematyka dotyczyła współpracy samorządu terytorialnego z grupami dyspozycyjnymi w zapewnianiu bezpieczeństwa na poziomie lokalnym.

Organizatorami konferencji byli: Urząd Marszałkowski Województwa Dolnośląskiego, Zakład Socjologii Grup Dyspozycyjnych Instytutu Socjologii Uniwersytetu Wrocławskiego, Akadémia Ozbrojenych Sil gen. M.R. Štefánika na Słowacji oraz Akademickie Koło Naukowe Security \& Society Instytutu Socjologii Uniwersytetu Wrocławskiego. Konferencję współorganizowali: Wyższa Szkoła Policji w Szczytnie, Zakład Socjologii Edukacji Instytutu Socjologii Uniwersytetu Wrocławskiego, wrocławski oddział Polskiego Towarzystwa Socjologicznego oraz Sekcja Socjologicznych Problemów Bezpieczeństwa Narodowego Polskiego Towarzystwa Socjologicznego.

Dwudniowa konferencja zgromadziła prelegentów i słuchaczy zarówno z kraju, jak i z zagranicy, którzy reprezentowali ośrodki akademickie i naukowo-badawcze, a także grupy dyspozycyjne oraz prywatny sektor bezpieczeństwa.

Konferencja rozpoczęła się powitaniem zgromadzonych gości przez Agnieszką Sokołowską, Dyrektor Wydziału Obronności i Bezpieczeństwa Urzędu Marszałkowskiego Województwa Dolnośląskiego oraz prof. dra hab. Jana Maciejewskiego, Kierownika Zakładu Socjologii Grup Dyspozycyjnych w Instytucie Socjologii Uniwersytetu Wrocławskiego. Uroczyste otwarcie konferencji objęło przemówienia Wicemarszałek Województwa Dolnośląskiego - Ewy Mańkowskiej, JM Rektora Uniwersytetu Wrocławskiego - prof. dra hab. Adama Jezierskiego, Dziekana Wydziału Nauk Społecznych UWr. - prof. dra hab. Roberta Wiszniowskiego oraz Dyrektora Instytutu Socjologii UWr. — prof. dra hab. Zbigniewa Kurcza. Otwierający konferencję zgodnie podkreślali, jak istotną wartością jest bezpieczeństwo we współczesnym świecie i wyrażali nadzieję na owocne obrady naukowe, będące przyczynkiem do umocnienia współpracy władz lokalnych z grupami dyspozycyjnymi systemu bezpieczeństwa państwa.

Wystąpienie prof. dra hab. Janusza Sztumskiego otworzyło pierwszą sesję plenarną i spotkało się z ciepłym przyjęciem. Profesor podkreślił najistotniejsze funkcje samorządu terytorialnego w rozwiązywaniu problemów z zakresu bezpieczeństwa publicznego na poziomie lokalnym. W wystąpieniu pt. Między propagandą a codziennością. Kobiety w oficjalnych publikacjach ISIS i Al-Kaidy prof. zw. dr hab. Marek Szczepański oraz dr Karolina Wojtasik zwrócili uwagę na kreowaną współcześnie przez światowe organizacje terrorystyczne konstrukcję kobiecości. Wystąpienie prof. dra hab. Włodzimierza Chojnackiego (Wyższa Szkoła Finansów i Zarządzania) pt. Realizm i instrumentalizm $w$ działaniach administracji publicznej $i$ wojskowej ukierunkowanych na przygotowanie obronne młodzieży podkreśliło doniosłą rolę edukacji dla bezpieczeństwa i zachowań proobronnych wśród młodego pokolenia. Profesor dr hab. Eugeniusz Moczuk (Politechnika Rzeszowska) omówił 
szeroko zagadnienie bezpieczeństwa lokalnego w perspektywie socjologii grup dyspozycyjnych, zaś prof. dr hab. Andrzej Pieczywok, dr Małgorzata Schneider oraz dr Waldemar Nowosielski skupili uwagę na stanie świadomości bezpieczeństwa obywateli. W swoim wystąpieniu odwołali się do wybranych środowisk województwa kujawsko-pomorskiego. O ostatnich doświadczeniach europejskich w zakresie bezpieczeństwa społeczności wielkomiejskich w kontekście zagrożenia terroryzmem opowiedział dr Piotr Pieńkowski (IS, Uniwersytet Wrocławski).

Doktor Małgorzata Stochmal (IS, Uniwersytet Wrocławski) swoje wystąpienie poświęciła zasadniczemu przedmiotowi własnej eksploracji naukowej - Państwowej Straży Pożarnej i Ochotniczej Straży Pożarnej, wskazując przede wszystkim potencjał OSP w kształtowaniu bezpieczeństwa na poziomie lokalnym. Prelegentka odwoływała się do empirycznych analiz z przeprowadzonych samodzielnie projektów badawczych, podkreślając szczególne cechy budujące kapitał społeczny funkcjonariuszy formacji pożarniczych w systemie bezpieczeństwa państwa.

Pierwszą sesję plenarną zakończyło wystąpienie mjr rez. dra inż. Jarosława Stelmacha, eksperta-praktyka w obszarze antyterroryzmu (Safety Project), pt. Bezpieczeństwo społeczności lokalnych wobec zagrożenia zdarzeniami o charakterze terrorystycznym. Podkreślił on ważny aspekt zmieniającej się natury współczesnego terroryzmu, wskazując przy tym na wypracowanie nowych metod działania ugrupowań terrorystycznych, w tym m.in. zastąpienie sytuacji zakładniczych aktywnym strzelcem oraz używanie samochodów jako narzędzia zamachu. Ponieważ współczesne incydenty o charakterze terrorystycznym mają krótki czas trwania, prelegent wyraźnie podkreślał konieczność zmiany charakteru reagowania, zwłaszcza w wymiarze wzmocnienia pierwszych uczestników - członków grup dyspozycyjnych, oraz wskazał na doniosłość edukacji dla bezpieczeństwa w tym zakresie.

Tematyka drugiej sesji plenarnej oscylowała wokół problemów grup militarnego, paramilitarnego, a także ochotniczego systemu bezpieczeństwa państwa. O roli kultury organizacyjnej Służby Więziennej w poprawie bezpieczeństwa lokalnego opowiedzieli płk mgr Anna Osowska-Rembecka (Centralny Zarząd Służby Więziennej) oraz ppłk mgr inż. Krystyna Zuwała (Okręgowy Inspektorat Służby Więziennej we Wrocławiu). Z kolei o profesjonalizacji poprzez zastosowanie kompetencji miękkich mówił mgr Grzegorz Fuchs (doktorant Wojskowej Akademii Technicznej) w wystąpieniu pt. Intuicja ekspercka i rozpoznawanie środowiska osadzonych przez funkcjonariuszy Służby Więziennej. Istotę instytucji zapewniających bezpieczeństwo socjalne oraz dbających o ład i porządek publiczny podkreślił prof. dr hab. Kazimierz Frieske (Akademia Pedagogiki Specjalnej), natomiast dr inż. Edyta Ślachcińska (Wyższa Szkoła Bankowa w Poznaniu) omówiła studium przypadku kooperacji samorządu lokalnego z jednostką wojskową w postaci lotniska wojskowego Poznań-Krzesiny. O celach i misji ochotniczej formacji wojskowej dla młodzieży opowiedziała dr Urszula Soler (Katolicki Uniwersytet Lubelski Jana Pawła II) w wystąpieniu pt. Legia Akademicka jako aktywny podmiot w polityce bezpieczeństwa lokalnego, dr Aneta Baranowska (Katedra Socjologii UKW w Bydgoszczy) wskazała zaś znaczenie grupy wsparcia dla weteranów wojennych i ich rodzin w wystąpieniu zatytułowanym Nieformalne systemy wsparcia społecznego dla weteranów i ich rodzin. Rola społeczności lokalnej.

Kolejna sesja plenarna objęła wystąpienia zagranicznych gości. Zainicjowało ją wystąpienie prof. dr Mariny Nuciari (Uniwersytet w Turynie) pt. Coping with diversity. Cultural adjustment and officers' education requirements for Crisis Response Operations in a multi- 
cultural world, w którym wskazała konieczność kulturowego dostosowania wymogów kształcenia oficerów. O zjawisku migracji we Włoszech oraz medialnym obrazie bezpieczeństwa, kształtowanym także przez media społecznościowe, mówił prof. dr Francesco Pira (Uniwersytet w Messynie) w wystąpieniu The perception of security in the communities. The narration trough media and social media. Focus on the migration phenomenon in Italy. Tłumaczeń obu wypowiedzi dokonywała dr Olga Nowaczyk (Uniwersytet Wrocławski). Kolejne wystąpienia były włoskojęzyczne i dotyczyły zjawiska kobietobójstwa na świecie (płk dr Orazio Anania, Włoskie Siły Zbrojne, Wyższa Szkoła Oficerska we Florencji) oraz syndromu wypalenia zawodowego w siłach porządkowych (prof. dr Marisa Aloia, Uniwersytet Sapienza w Rzymie). Na język polski tłumaczyła mgr Jolanta Grębowiec-Baffoni (doktorantka, Uniwersytet Wrocławski).

Czwarta sesja plenarna była ostatnią w pierwszym dniu konferencji. W jej trakcie prelegenci przedstawili pięć wystąpień tematycznych. Zagrożenia dla bezpieczeństwa wewnętrznego w Republice Słowackiej przybliżył prof. Vojtech Jurcak (Armed Forces Akademy of generála Milana Rastislava Štefánika), wolontariat Ochrony Cywilnej we Włoszech omówiła dr Elena Castiello, zaś altruizm wolontariuszy Ochrony Cywilnej wobec ofiar trzęsienia ziemi w środkowych Włoszech rzeczowo skomentował inż. Enzo Natali (Międzygminna Grupa Wolontariuszy Ochrony Cywilnej Unii Gmin Valconca, prowincja di Rimini). Wystąpienie prof. dra Nicoli Strizzolo (Uniwersytet w Udine) oraz prof. dra Mario Ianniello (Uniwersytet w Udinie) pt. Italian Red Cross communication strategies 19151918: Managing and mastering public relations przybliżyło historyczne aspekty włoskich strategii komunikacji z Międzynarodowym Ruchem Czerwonego Krzyża i Czerwonego Półksiężyca. Wystąpienie dr Barbary Bojack pt. Sexuell ubergriffige Kinder und Jugendliche, Erkennen von Risikfaktoren zur Pravention und Sicherheit in Gemeinden, ostatnie w pierwszym dniu konferencji, dotyczyło różnorodnych aspektów przemocy seksualnej wśród dzieci i młodzieży w kontekście bezpieczeństwa w społecznościach lokalnych.

Drugi dzień konferencji rozpoczął się piątą sesją plenarną, podczas której przedstawione zostały takie obszary, jak polityka społeczna na tle bezpieczeństwa społecznego (prof. Krystyna Leśniak-Moczuk, Uniwersytet Rzeszowski), konflikt hybrydowy w kontekście Polski (dr Michał Piekarski, WNS, Uniwersytet Wrocławski) oraz społeczna konstrukcja ryzyka w cyberprzestrzeni (dr Alina Betlej, mgr Arkadiusz Leśniak-Moczuk, Katolicki Uniwersytet Lubelski Jana Pawła II). Prelegenci zaprezentowali także rolę dzielnicowego w środowisku lokalnym oraz istotę community policing (dr Edward Palka, Wyższa Szkoła Bankowa w Poznaniu), działalność ośrodków pomocy społecznej na rzecz ofiar zdarzeń nadzwyczajnych (dr Sławomir Wilk, Uniwersytet Rzeszowski) oraz organizację ochrony ludności w gminie Lewin Brzeski (dr Roman Odżga, Urząd Miejski w Lewinie Brzeskim). Relacje pomiędzy samorządem a edukacją seniorów przedstawił dr Józef Młyński (Uniwersytet Kardynała Stefana Wyszyńskiego w Warszawie), strategie radzenia sobie z traumą wojenną przez weteranów misji wojskowych — dr Beata Czuba (Wojskowa Akademia Techniczna), a współpracę samorządu lokalnego i wojsk obrony terytorialnej w zapewnieniu bezpieczeństwa ekologicznego wyeksponował dr Janusz Okrzesik (Akademia Ignatianum w Krakowie).

Ostatnia sesja plenarna rozpoczęła się wystąpieniem dra Bogdana Ćwika (Wojskowa Akademia Techniczna) pt. Postrzeganie zagrożeń w warunkach silnych napięć emocjonalnych. Problematykę wpływu patologii społecznej na opinie o bezpieczeństwie podniósł 
dr Tadeusz Iwanek (Państwowa Wyższa Szkoła Zawodowa w Nysie), filozofię bezpieczeństwa antyterrorystycznego zaś przybliżył mgr Wojciech Mackiewicz (Uniwersytet Wrocławski). Kolejne wystąpienia dotyczyły umiejętności udzielania pomocy przedmedycznej na przykładzie członków grup dyspozycyjnych w powiecie lwówieckim (mgr Helena Liśniewska, doktorantka Akademii Marynarki Wojennej), nowoczesnych technologii wykorzystywanych w analizie przestępczości lokalnej (mgr Arkadiusz Leśniak-Moczuk i dr Alina Betlej z Katolickiego Uniwersytetu Lubelskiego), społecznego postrzegania działalności samorządu lokalnego na rzecz bezpieczeństwa (dr hab. prof. WSB Wojciech Horyń, Wyższa Szkoła Bezpieczeństwa w Poznaniu), kształtowania postaw pro-bezpiecznych (dr Jolanta Horyń, Wyższa Szkoła Bezpieczeństwa w Poznaniu), bezpieczeństwa przeciwpowodziowego (dr Joanna Filaber, Wyższa Szkoła Prawa im. H. Chodkowskiej we Wrocławiu) oraz zagrożenia przestępczością w zbiorowościach miejskich (dr Monika Zawartka-Czekaj, Uniwersytet Wrocławski). Konferencję zwieńczyło uroczyste podsumowanie prof. dr hab. Jana Maciejewskiego.

Problematyka badawcza dwudniowej konferencji dotyczyła współpracy władz lokalnych z grupami dyspozycyjnymi militarnego, paramilitarnego i cywilnego systemu bezpieczeństwa lokalnego. Eksploracja zagadnień z tej sfery naukowej pozwoliła na wypracowanie wniosków i konkluzji pozwalających w przyszłości na wzmocnienie kooperacji, a także na jej reorganizację z uwzględnieniem dynamiki przemian współczesnych zagrożeń bezpieczeństwa na poziomie lokalnym. W świetle zaprezentowanych wystąpień badaczy akademickich, ekspertów oraz praktyków sfery bezpieczeństwa zorganizowanie wysokiego stanu bezpieczeństwa lokalnego stanowi niezwykle ważne zadanie dla samorządu lokalnego oraz wszystkich grup dyspozycyjnych. To wpłynie na wzmocnienie rozwoju społecznego „małych ojczyzn”.

Aneta Urbaniak 